\title{
Equity Gaps in Education: Nine Points toward More Transparency
}

\author{
Albert Ziegler ${ }^{1, *}$, Ching-Chih Kuo ${ }^{2}$, Sen-Peng Eu ${ }^{3}$, Michaela Gläser-Zikuda ${ }^{4}$, Miguelina Nuñez ${ }^{1}(\mathbb{D}$, \\ Hsiao-Ping $\mathrm{Yu}^{2}$ a and Bettina Harder ${ }^{1}$
}

1 Department of Psychology, Friedrich-Alexander University, 90,478 Nürnberg, Germany; miguelina.nunez@fau.de (M.N.); bettina.harder@fau.de (B.H.)

2 Department of Special Education, National Taiwan Normal University, Taipei 106, Taiwan; kaykuo@ntnu.edu.tw (C.-C.K.); ping0623@ntnu.edu.tw (H.-P.Y.)

3 Department of Mathematics, National Taiwan Normal University, Taipei 116, Taiwan; senpengeu@gmail.com

4 Department of Education, Friedrich-Alexander University, 90,478 Nürnberg, Germany; michaela.glaeser-zikuda@fau.de

* Correspondence: albert.ziegler@fau.de

check for updates

Citation: Ziegler, A.; Kuo, C.-C.; Eu, S.-P.; Gläser-Zikuda, M.;

Nuñez, M.; Yu, H.-P.; Harder, B. Equity Gaps in Education: Nine Points toward More Transparency. Educ. Sci. 2021, 11, 711. https:// doi.org/10.3390/educsci11110711

Academic Editor: James Albright

Received: 31 August 2021

Accepted: 28 October 2021

Published: 4 November 2021

Publisher's Note: MDPI stays neutral with regard to jurisdictional claims in published maps and institutional affiliations.

\begin{abstract}
The aim of this paper is to increase transparency in the scientific analysis of equity gaps in education. This should be useful in avoiding common ambiguities and misunderstandings in the discourse and in presenting the analyses results in a constructive way. We focused on a very basic aspect of transparency: Information availability. We identified nine topics related to the constitutive terms: "equity", "gap", and "education", topics for which information is often only implicitly or selectively transmitted or not transmitted at all. Regarding the constitutive term "equity", and as the possible sources of transparency problems, we analyzed (1) the type of equity model, (2) the underlying distribution model, and (3) the group concept between which equity gaps exist. For the clarification of the constitutive term "gap", we addressed (4) the applicability issue, (5) the indicator issue, (6) the reference issue, and (7) the significance issue. The last two sources of transparency problems were related to the constitutive term "education" and referred to (8) the location of the equity gap within or outside education and (9) the characterization of the equity gap within education. For each of the nine topics, we highlight the biggest problems of understanding and propose solutions.
\end{abstract}

Keywords: equity gap; education; transparency

\section{Equity Gaps in Education: Nine Points toward More Transparency}

In the social and life sciences, there are continuous efforts to improve the quality standards for scholarly discourse and communication. For example, among other things, definitions, conceptual analyses, and the setting of methodological, statistical, publication, and presentation standards contribute to better clarity. Notably, given the replication crisis in the social and life sciences, it has become increasingly clear that enhancing transparency is an important desideratum [1,2]. However, transparency is a multidimensional construct with many facets [3-5]. There exists a possibility, nonetheless, for increased transparency through the establishment of transparency standards that could, in turn, serve quite a number of different objectives. In the scientific community, particularly in medicine, such standards have existed for a long time, e.g., [6] and are now being adopted in other disciplines [7-9].

One of the objectives of such standards is to avoid difficulties in understanding spurred by a lack of essential or only implicitly given information anent key concepts or scientific terms. Indeed, across disciplines in the social and life sciences, many publications fail to fully disclose hidden theoretical assumptions underlying their research and do not consistently provide the information needed for the reproducibility of the studies [10-13].

In our case, we are particularly concerned with equity gaps in education. We consider this topic extremely important but have repeatedly encountered difficulties in its 
comprehension, especially in the reception of the literature and in scientific discourses. In particular, we will identify nine fields where we hope to see more transparency as well as a more thorough disclosure of information in the future.

\section{Equity Gaps in Education}

Equity is a key value of modern societies and their education systems [14-17]. However, there is a growing awareness of how large the gap is between desire and reality. According to a recent observation by Leithwood [18], "concerns about inequity have never been more widespread or garnered more public energy than they do now" (p. 377). Equity gaps in education - usually understood as disparities between groups in educational outcomes that violate notions of equity [19] — have been identified in virtually all societal fields $[17,20,21]$. They include social class [22-24], race and ethnic groups [25-27], gender [28-30], sexual orientation and identity [31-33], and many more. Furthermore, there are many different types of equity gaps in education, such as achievement gaps [34], excellence gaps [35], funding gaps [36], confidence gaps [37], and threshold gaps [38]. In the efforts to close equity gaps, education undoubtedly plays a pivotal role [15,16,39-42]. Indeed, there have even been calls for an 'equity pedagogy' of its own [43,44].

With the growing interest in equity gaps in education, however, come several challenges. We agree with Mel Ainscow's [39] assertion that, despite numerous attempts to address equity in education, "the field remains confused" (p. 7). A reason for this can be "limited conceptual clarity, or shared consensus, in defining and explaining many of our major concepts, creating myriad problems" [45] (p. 42).

According to Hjørland [46], concepts such as equity gaps in education are "dynamically constructed and collectively negotiated meanings that classify the world according to interests and theories" (p. 1522-1523). While all competent English speakers have some understanding of the phrase 'equity gap in education', its constituent terms "equity", "gap", and "education" are words of everyday vocabulary and thus fuzzy with non-exact designation. However, whenever we use the phrase 'equity gap in education,' we classify the equity gap(s) in education phenomenon as "importantly similar to other entities bearing the same designation" [47] (p. 292). However, this leads to the problem of conceptual unity, which is critical, especially for ethical concepts such as equity [48]. The extension of a concept can indeed become too fuzzy; conceptual unity refers to the realistic possibility that all the involved parties are discussing different things. In such a case, the natural first step would be to name the areas where these ambiguities arise.

\section{Transparency}

While scientific concepts can often emerge from everyday concepts, the requirements for clarity then become disproportionately greater [49,50]. However, we believe it is illusory to attempt to bring about consensus regarding the meaning or even a definition of the constituent terms or of the entire phrase, 'equity gap in education.' This has not yet been achieved in the long history of English language etymology, nor has it for aequitās (Latin for equity) or for $\bar{e} d u c \bar{a} t i \overline{\bar{a}}$ (Latin for education). Recent analyses of the use of the term equity in education also reveal enormous linguistic diversity [21].

Similarly, as there is no consensus regarding a definition or a conceptualization of "equity gap in education", there is no consensus at a meta-theoretical level regarding the meaning or even the construction of the definitions or concepts [51]. On the one hand, in the absence of such standards, and on the other, given the practical difficulties of establishing consensus in a heterogeneous field of research with many ramifications in other academic disciplines, we would like to propose a more modest goal: increasing the transparency of the use of the phrase 'equity gap in education' (for some excellent conceptual analyses, see [52-54]).

In line with Moravcsik [55], we do trust that transparency is an almost unquestionable value in the scientific community: "Almost all social scientists recognize research transparency — defined as the obligation to make data, analysis, methods, and interpretive 
choices underlying their claims visible in a way that allows others to evaluate them-as a fundamental ethical obligation" (p. 2). Of course, such a general consensus does not signify that there is agreement on what transparency should cover in detail [56,57].

Transparency can be traced back to the medieval Latin word transparentum ("the quality of being easy to see through" [58]). It can be considered as a regulatory or voluntary requirement in the interdisciplinary efforts of a scholastic community to achieve scientific progress [59]. Increasing transparency increases the likelihood that information will be interpreted correctly among researchers, educators, policy analysts, policymakers, and other stakeholders. It also aids in the review and replication of scientific findings in particular. To this end, we would like to propose a slightly modified definition of transparency from Hosseini et al. [59] (p. 253) as a working definition:

As stakeholder A, I want to understand information from stakeholder B, so that I can make full use of the information in my decision-making.

Or as follows:

As stakeholder A, I want to give information to stakeholder B, so that stakeholder B can understand the information and make full use of it in their decision-making.

In the following section, we identify nine issues about which stakeholder B should (want to) request explicit commentary from stakeholder A. Thus, we essentially focused on a very basic aspect of transparency: Information availability. We discuss nine topics, sorted by the three constitutive terms: 'equity', 'gap', and 'education', where we would have liked to see more transparent information from Stakeholder A (see Figure 1).

\section{EQUITY GAPS IN EDUCATION}

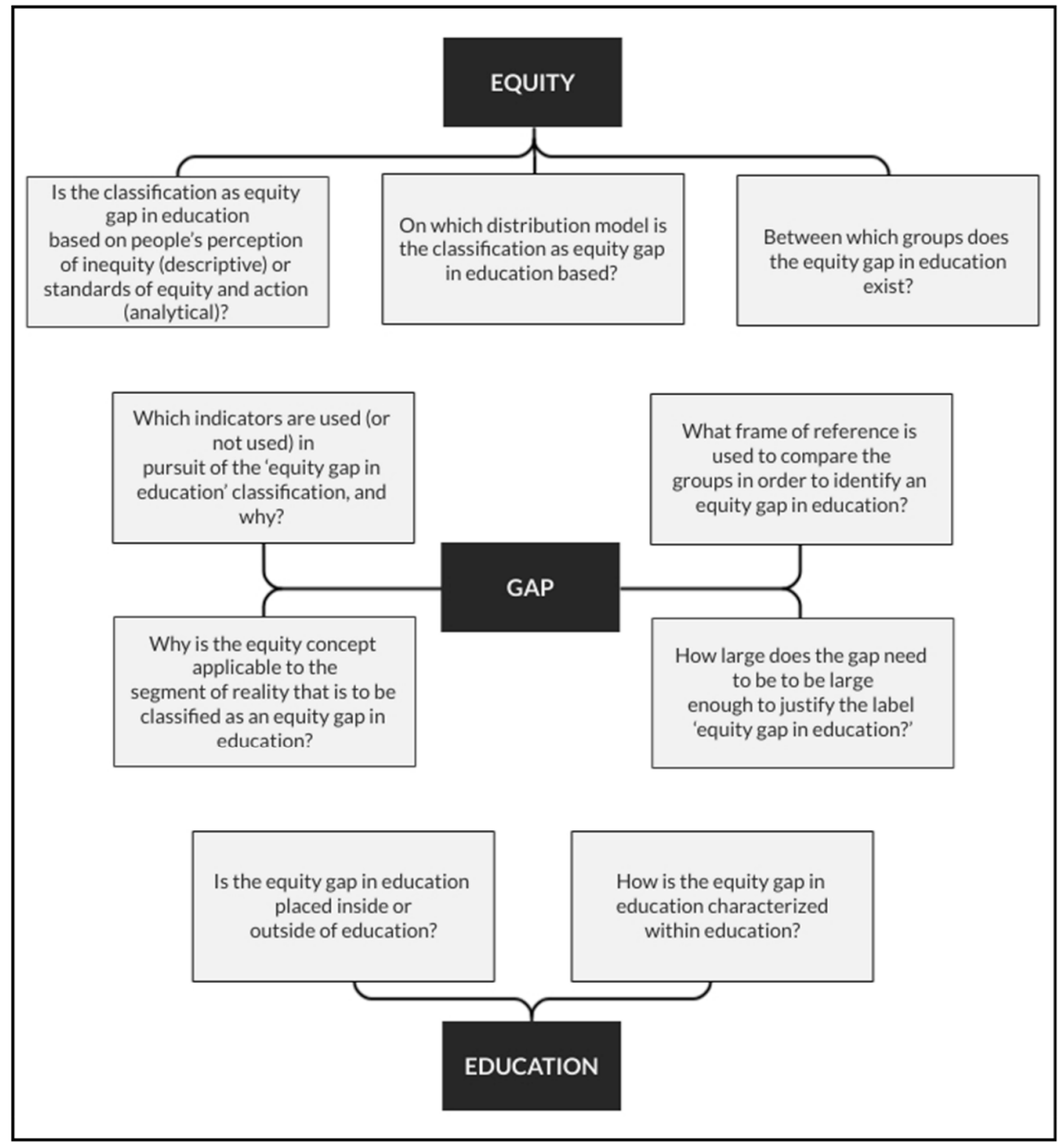

Figure 1. Nine points toward more transparency when addressing equity gaps in education. 


\section{Equity}

Despite many attempts to clarify the term 'equity', a common understanding is out of reach (e.g., [60]). We see a need for clarification in three specific regards.

\subsection{Descriptive or Analytical Equity Models}

First, it is important to consider whether equity is conceptualized from the perspective of descriptive ethics ("what do people believe is right or just?" [61]) or analytical ethics ("what is right and just and how should people act?" [62]). Both approaches have advantages and disadvantages for an analysis of equity gaps in education. A major disadvantage of descriptive ethics is that there are large interindividual differences in perceptions of equity gaps in education (e.g., [63,64]). Stakeholder A should, therefore, identify the stakeholders that he or she believes share in this exact understanding of equity. Among other things, this would be important for the addressee-related planning of measures.

However, the same diversity of descriptive ethics also prevails in analytical ethics anent 'equity'. On the one hand, there are varieties of nihilism, that is, values and principles of justice that are denied in principle. This would fundamentally exclude the existence of equity gaps. However, even if values and principles of equity are accepted, the possible spectrum is wide. It ranges from a monistic view of a gap (only one equity principle of a gap operates) to a relativistic view (equity principles are only valid for a particular group, but gaps do not hold across individuals or groups). Pluralistic views can be located as the middle ground of the two positions $[65,66]$. These positions may arrive at entirely different assessments. For example, what is not an equity gap from the perspective of meritocratic ethics [67] may be a blatant injustice from the perspective of the ethics of compassion [68]. Clarity is therefore needed for Stakeholder A and B on what basis a gap is assessed or dismissed as an equity gap.

\subsection{Distribution Model}

Our initial analytical considerations have already made it clear that it is extremely difficult to reach agreement on the equity concept as used to evaluate gaps. Therefore, it is even more important to ensure transparency and to disclose the use of the equity concept. However, it is not sufficient to state which descriptive or analytical equity concept is used and whether it is used. The ultimate goal should be to be able to relate pedagogical research on equity gaps in education to each other, thus avoiding the equivocal discourse trap. In this context, it is particularly important to distinguish between equality and equity.

While equality usually refers to having the same resources and opportunities, equity often means a redistribution of resources and opportunities to allow for greater equality [25]. Equity thus "involves a normative judgement of a distribution, but how people make that judgement will vary" [69] (p. 17). However, despite all the differences in approaches, such as Marxism, utilitarianism, and communitarianism, there exists a connecting link. As virtually all the concepts of equity imply some form of equality [70], almost all ethical approaches use at least one, often several, distribution models. Therefore, both specifications-which descriptivist-ethical approach or which analytic-ethical approach and which distribution models-are necessary.

We propose to distinguish three basic concepts of distribution models in Stakeholder A's specifications, which are similar to the UNESCO Institute for Statistics [69] recommendation. Again, while we do not want to take a position on which distribution model is better, we always want to know, having assumed the role of Stakeholder B, which distribution models have been applied.

In the Identical Distribution Model, the indicators of equity, such as achievements, participation rates, and opportunities must be identical. Otherwise, they signal a gap. The Meritocratic Distribution Model, on the other hand, takes into account the contribution of those who benefit from the distribution. Under this model, for example, it might be considered equitable for children already advantaged in many respects to be enrolled in additional enrichment programs on the basis of their current learning achievements, which 
of course are due to the children's beneficial situation, further enhancing their learning conditions for the future, ultimately resulting in a snowball effect. The Need-Based Distribution Model incorporates learning needs into equity considerations, thereby accounting for the snowball effects. This model points out that equal or meritocratic educational inputs can potentiate the effects of previously asymmetric educational inputs. This is the case, for example, when more resource-rich stakeholders provide unequal starting conditions for some of the students' learning trajectories [71]. Ceci and Papierno [72] showed that many educational-science interventions have the effect of widening the existing gaps between disadvantaged and advantaged groups. Therefore, it is almost inevitable that closing an equity gap requires that the disadvantaged group receive interventions that the advantaged group does not. According to this model, equal input would not be equitable; rather, disadvantaged groups would have to receive relatively more input.

\subsection{Groups}

Equity gaps in education are based on disparities between the actors and groups that violate notions of equity-whether based on a descriptive or an analytical concept of equity-and whatever distribution models are applied. Indeed, a clear identification of the groups is needed. One field where the urgency of precise specification is increasingly recognized is that of gender gaps in education. Obviously, it is not enough here to distinguish between male and female. Rather, the multiple disadvantages of trans and non-binary persons need to be accurately captured [73,74].

A major criticism of the original concept of equity gaps was that it was narrowed to differences between groups while it overlooked the considerable variance within groups [75,76]. For example, Peters [77] points out that within ethnic/racial disparities there is a great diversity of experience. 'Black', for example, can refer to voluntary immigrants from the Caribbean as well as to refugees from Somalia. Similarly, 'Asian' can refer to Hmong farm workers in rural Wisconsin who are homeless and speak English as a second language as well as to the children of tech-sector employees in Fortune 100 companies. Thus, equity gaps between People of Color $(\mathrm{PoC})$ and Caucasians may be a consequence of racism, but equity gaps may also exist within groups of $\mathrm{PoC}$, indicating other influencing factors. Therefore, even if the groups can be clearly identified, Stakeholder A should provide relevant information on the variance within these groups.

It is also important to note that individuals can be disadvantaged in several regards and thus can be affected by multiple equity gaps. Therefore, several authors rightly caution that a broader perspective on gaps should be taken [78]. Admittedly, the intersectionality of disadvantages does complicate the identification of different overlapping equity gaps. However, because equity gaps may only emerge through the interaction of disadvantages, or an equity gap may be mistakenly attributed to a disadvantage, accurate naming of possible intersectionality is imperative for full transparency.

\section{The Gap}

So far, we have discussed equity gaps in education on a conceptual level. In the discussion of the gap that follows, we ask how the conceptual perspective can be applied to a particular aspect of reality, i.e., the field of education. Establishing the gap requires answers to four problems, addressed below as the applicability issue, the indicator issue, the reference issue, and the significance issue. In favor of simplicity in these analyses, we assume that we are in fact always addressing phenomena that fall within the scope of education. We will return to our usual application of the term 'education' in the subsequent section.

\subsection{Applicability Issue}

The term "gap" refers to identifiable systematic differences between groups. However, not every difference between groups signals a potential equity gap. As a first step, Stakeholder A should clarify why a gap can be evaluated by an equity standard. To do this, we need to apply the conceptual considerations of equity mentioned above to education. 
For many aspects of education, it seems entirely intuitive that issues of equity are involved. For example, we immediately see the importance of disparities between groups in their access to and their participation in schooling, or disparities in outcomes such as good academic performance for better life chances (e.g., upward or class mobility). Nonetheless, one person's everyday intuition may be incongruent with another person's equity intuition [79]. Indeed, equity contexts can be ambiguous and contextual. Consider daily caloric intake: that male adolescents consume more calories than female adolescents does not appear to be an equity problem. However, it can become an equity problem when poverty and social class make it difficult to obtain sufficient calories, even within rich societies [80]. This food insecurity can affect developmental and academic outcomes [81-83].

\subsection{Indicator Issue}

After deciding whether a concept of equity can be applied to an aspect of reality, the next step is to determine which indicators can be used for this purpose. From a research perspective, these are questions regarding measurement. For example, the equal academic performance of two groups may not be indicative of equity. Well-known examples include the performance or achievements of refugees [84] or of women in STEM [85] in higher education. Consider that in order to compare male student performances to that of students from nonimmigrant backgrounds, it is necessary to take into account whether male student performers only represent an elite minority of a larger (minority) group, and whether they had to overcome the unfavorable effects of negative stereotyping. A transparent selection of indicators, therefore, requires Stakeholder A, among other things, to justify why these particular indicators were chosen while others were not. For example, whether indicators of equal potential, achievement, or opportunity are chosen can make a big difference regarding the determination of an equity gap [52].

\subsection{Reference Issue}

When Stakeholder A identifies a gap, comparisons are made. However, in addition to the dimensions of measurement as well as the groups involved, the identification of a gap also requires the definition of a frame of reference. Stakeholder A can accomplish this, for example, by using different concepts, such as 'no child left behind' or 'equality on average across the social groups.' Diverse statistical measures are also possible, such as differences, ratios, dispersions, or cumulative information such as the Gini coefficient [69]. Here, too, we consider it important that Stakeholder A takes the usual transparency standards into account, including completeness of information, mention of alternatives, etc.

\subsection{Significance Issue}

Surprisingly little is known about who recognizes what inequality and when [86]. The fact is, there is no objective criterion for when an equity gap in education is actually significant, i.e., neither random nor negligibly small. Therefore, it seems illusory to try to establish a consensus regarding cut-off points with respect to significance. This would require a decision as to whether, for example, statistical measures, the majority's intuition of equity, or feelings of discrimination against the disadvantaged should be used. We would expect full disclosure as to when and why Stakeholder A classifies a difference between groups as so significant that it represents an equity gap.

\section{Education}

There exists a plethora of definitions for education and the concepts of education. They range from general stipulations, including those underscored by Kohlberg and Mayer [87] as "development as the aim of education" (p. 449), to concrete classifications such as that which the OECD [88] classified as pursuant to education levels and fields. However, the breadth of these definitions and discussions-e.g., nature vs. nurture or education vs. socialization-indicate that it is hopeless to attempt a consensual definition or conceptual analysis of education. Instead, we would like to re-emphasize the points that we think are 
necessary for a better understanding of the stakeholder reliance on the phrase 'equity gaps in education' as it relates to the conceptualization of education therein.

\subsection{Placing the Equity Gap Inside or Outside of Education}

Arguably, the most easily overlooked word in the phrase 'equity gaps in education' is the preposition 'in'. Although it sounds like a contradictio in adjecto, it makes sense to distinguish among equity gaps in education, specifically whether they are located in or outside of the education system. Equity gaps within education could be, for example, low attendance, high drop-out rates, and school achievement. Examples of equity gaps outside the education system include career opportunities for disadvantaged groups transitioning from the education system to the workforce. For the aforementioned equity gaps, it is not yet clear that the education system played a significant role in their formation. Moreover, the education system's potentially passive role, i.e., when the system could have contributed to preventing the emergence of the equity gap, must also be considered.

Locating the equity gap in or outside of the education system is important to the identification of which societal subsystem—in systems theory jargon—controls this gap [89-91]. This is particularly important when deciding from where action should spring in the furtherance of closing a given equity gap. For example, Kohli et al. [92] drew attention to the fact that in peer-reviewed educational scholarship, words such as 'multicultural(ism)' and 'achievement gap' are up to eight times more frequent than concrete discussions of racism. Obviously, there is a serious danger in overlooking what the actual causes of an equity gap might be because, undoubtedly, the processes that led to the development of inequalities are often embedded in even broader contexts that extend beyond the situation and the education system itself. It might include, for example, historical or societal or even global processes. Stakeholder A should thus be precise in communicating assumptions about where an equity gap in education is located. Do they end at the boundaries of the education system?

\subsection{Characterization of the Equity Gap within Education}

Each equity gap in education has its own history, is based on individual personal experiences, and requires specific measures to bridge. From an educational perspective, however, the question arises as to whether equity gaps in education are conceptually incommensurable or whether there exist commonalities that enable the development of overarching pedagogical strategies. However, to find out, appropriate categorization is needed. Such a categorization acts, in a sense, like lenses. Through them, Stakeholder A and Stakeholder B can help identify commonalities between equity gaps in education. Looking through the lenses of categorization also allows for the specifics of the gaps to emerge clearly.

Stakeholders A and B can use various strategies. One way would be for Stakeholder A to categorize equity gaps in education into one of three gaps: opportunity gap, learning gap, and outcome gap. These three types of equity gaps in education are distinguished for analysis purposes, but in reality, they are inseparable parts of the same process. The three terms merely provide different perspectives on the same dynamic process that occurs on different time scales and that ultimately leads to inequalities. However, we think that taken together, from an educational perspective, the three terms can provide a conceptual key to understanding and bridging equity gaps in education. We propose to conceptualize them as three interrelated aspects of the educational processes, see [93-95]:

- Opportunity gaps denote unequitable input of (educational) processes; for example, resources, opportunities, access to infrastructure, and learning opportunities.

- Learning gaps denote unequitable capacities to take advantage of opportunities, resources, access to infrastructure, and learning opportunities.

- Outcome gaps denote unequitable output of (educational) processes, e.g., participation rates, learning outcomes, achievements, and rewards. 
Distinguishing the three types of gaps according to their dual function-making commonalities visible, but also specific_immediately increases the transparency of Stakeholder A and B's communication from an educational perspective. For example, Stakeholder A can categorize the phenomenon of low proportions of female CEOs in the STEM field as an opportunity gap that also appears in the course choices at school and in the choice of STEM subjects at universities. However, the gaps are less extreme the lower the academic level. By characterizing a given equity gap as an opportunity gap that has certain commonalities but that is also unique relative to other opportunity gaps, Stakeholder A connects the gap in question to relevant knowledge gathered in pedagogy and thus connects with Stakeholder $\mathrm{B}$ on a basis of professional understanding.

\section{Discussion}

Equity is a central goal of education. However, critical introspection quickly reveals that there are a huge number of equity gaps in education $[17,20,21]$. In recent years, numerous scholars in various fields of education have uncovered a myriad of gaps while attempting to find ways to bridge those very gaps. As welcome as this lively participation has been, the many voices involved have probably contributed unwillingly to the fact that, often, equity gaps in education are talked about differently [64]. It is natural then to examine where these ambiguities arise. To avoid them is to avoid critical steps toward the production of cumulative, actionable knowledge on equity gaps in education.

Improving communication in a scientific community can depend on a variety of strategies. It is undeniable that the latter requires, among other things, conceptual analyses or explicit definitions [52-54]. A more modest goal, that is nevertheless extremely important, is to increase transparency. Calling for transparency criteria in no way means that we want to discourage scholars from proposing new definitions or conceptual analyses of equity gaps in education. We believe that scholarly competition for ever-better definitions and conceptual analyses is fruitful. However, the transparency criteria we propose can certainly help improve the standards that consensual definitions and conceptual analyses must meet.

We proposed to understand transparency as the successful communication between stakeholder A (as the presenter of information) and B (as the recipient of information), cf. [59], where stakeholders can be, for example, researchers, educators, policy analysts, or policymakers. We focused on a very simple aspect of transparency: Information availability. The goal was to identify information on specific topics that is often given only implicitly, diffusely, misleadingly, or not at all. The goal was explicitly not to present a definition or a complete conceptual analysis.

We presented nine topics, sorted by the three constitutive terms: 'equity', 'gap', and 'education', where we would have liked to see more transparent information from Stakeholder A. We expect Stakeholder A to provide information anent (1) the type of equity model, (2) the underlying distribution model, and (3) the group concept between which equity gaps exist. For the clarification of the constitutive term "gap", we addressed (4) the applicability issue, (5) the indicator issue, (6) the reference issue, and (7) the significance issue. The last two sources of transparency problems were related to the constitutive term "education" and referred to (8) the location of the equity gap within or outside education and (9) the characterization of the equity gap within education. This list is certainly incomplete. For example, it could be discussed whether the educational goals behind the use of the phrase 'equity gap in education' should be included. After all, it may well be of interest whether authors aim for equal opportunities [96] or even equal outcomes [97] as educational goals. However, we took as our starting point the constitutive terms 'equity', 'gap', and 'education'. In using our list in conversations and critical discussions with colleagues, our experience so far has been that it is sufficient to increase the transparency of communication in a way that is satisfactory to us. However, we explicitly call on the scientific community to supplement our list with additional items about which they hope for more clarity and less misunderstanding. 
In conclusion, the authors of this article want to express their hope that our list of points will quickly prove to be redundant. If item after item were to disappear from this list because our call was noticed by Stakeholder A and had thus helped to improve communication within our scientific community, we would be one step closer to our goal of a self-critical, self-correcting, ever-evolving practice in analyzing and communicating about equity gaps in education.

Author Contributions: Conceptualization, A.Z., C.-C.K., S.-P.E., M.G.-Z., H.-P.Y., B.H.; WritingOriginal Draft Preparation, A.Z.; Writing—Review \& Editing, A.Z., M.N., B.H.; All authors have read and agreed to the published version of the manuscript.

Funding: This research received no external funding.

Conflicts of Interest: The authors declare no conflict of interest.

\section{References}

1. Landis, S.C.; Amara, S.G.; Asadullah, K.; Austin, C.P.; Blumenstein, R.; Bradley, E.W.; Crystal, R.G.; Darnell, R.B.; Ferrante, R.J.; Fillit, H.; et al. A call for transparent reporting to optimize the predictive value of preclinical research. Nature 2012, 490, 187-191. [CrossRef]

2. Iqbal, S.A.; Wallach, J.D.; Khoury, M.J.; Schully, S.D.; Ioannidis, J.P. Reproducible Research Practices and Transparency across the Biomedical Literature. PLoS Biol. 2016, 14, e1002333. [CrossRef] [PubMed]

3. Damian, E.; Meuleman, B.; van Oorschot, W. Transparency and Replication in Cross-national Survey Research: Identification of Problems and Possible Solutions. Sociol. Methods Res. 2019. [CrossRef]

4. Pratt, M.G.; Kaplan, S.; Whittington, R. Editorial Essay: The Tumult over Transparency: Decoupling Transparency from Replication in Establishing Trustworthy Qualitative Research. Adm. Sci. Q. 2020, 65, 1-19. [CrossRef]

5. Wolf, C.; Joye, D.; Smith, T.; Fu, Y.-C. The SAGE Handbook of Survey Methodology; Sage: Los Angeles, CA, USA, 2016.

6. CONSORT. CONSORT: Transparent Reporting of Trials. 2010. Available online: http://www.consort-statement.org/home/ (accessed on 2 November 2021).

7. American Psychological Association. Publication Manual of the American Psychological Association, 6th ed.; APA: Washington, DC, USA, 2010.

8. Atkinson, K.M.; Koenka, A.C.; Sanchez, C.E.; Moshontz, H.; Cooper, H. Reporting standards for literature searches and report inclusion criteria: Making research syntheses more transparent and easy to replicate. Res. Synth. Methods 2015, 6, 87-95. [CrossRef]

9. Snyder, H. Literature review as a research methodology: An overview and guidelines. J. Bus. Res. 2019, 104, 333-339. [CrossRef]

10. Aguinis, H.; Solarino, A.M. Transparency and replicability in qualitative research: The case of interviews with elite informants. Strateg. Manag. J. 2019, 40, 1291-1315. [CrossRef]

11. Hamra, G.B.; Goldstein, N.D.; Harper, S. Resource Sharing to Improve Research Quality. J. Am. Heart Assoc. 2019,8 , e012292. [CrossRef]

12. López-Nicolás, R.; López-López, J.A.; Rubio-Aparicio, M.; Sánchez-Meca, J. A meta-review of transparency and reproducibilityrelated reporting practices in published meta-analyses on clinical psychological interventions (2000-2020). Behav. Res. Methods 2021, 1-16. [CrossRef]

13. Rauh, S.; Torgerson, T.; Johnson, A.L.; Pollard, J.; Tritz, D.; Vassar, M. Reproducible and transparent research practices in published neurology research. Res. Integr. Peer Rev. 2020, 5, 1-9. [CrossRef]

14. Hayes, D.; Talbot, D.; Mayes, E. Diffractive accounts of inequality in education: Making the effects of differences evident. Int. J. Qual. Stud. Educ. 2020, 33, 357-371. [CrossRef]

15. UN. Sustainable Development Goal 4: Targets and Indicators. Available online: https://sustainabledevelopment.un.org/sdg4 \#targets (accessed on 13 August 2021).

16. UNESCO. Education 2030: Incheon Declaration and Framework for Action for the Implementation of Sustainable Development Goal 4. Towards Inclusive and Equitable Quality Education and Lifelong Learning Opportunities for All. UNESDOC Digital Library. 2015. Available online: https:/ /iite.unesco.org/publications/education-2030-incheon-declaration-framework-actiontowards-inclusive-equitable-quality-education-lifelong-learning/ (accessed on 2 November 2021).

17. Welch, A.; Connell, R.; Mockler, N.; Sriprakash, A.; Proctor, H.; Hayes, D.; Foley, D.; Vickers, M.; Bagnall, N.; Burns, K.; et al. Education, Change and Society, 4th ed.; Oxford University Press: Melbourne, Australia, 2018.

18. Leithwood, K. A Review of Evidence about Equitable School Leadership. Educ. Sci. 2021, 11, 377. [CrossRef]

19. Brown McNair, T.; Bensimon, E.; Malcom-Piqueux, L. From Equity Talk to Equity Walk: Expanding Practitioner Knowledge for Racial Justice in Higher Education; Jossey-Bass: Hoboken, NJ, USA, 2018.

20. Ainscow, M.; Dyson, A.; Goldrick, S.; West, M. Developing Equitable Education Systems; Routledge: London, UK, 2012.

21. Jurado de los Santos, P.; Moreno-Guerrero, A.-J.; Marín-Marín, J.-A.; Soler Costa, R. The term equity in education: A literature review with scientific mapping in Web of Science. Int. J. Environ. Res. Public Health 2020, 17, 3526. [CrossRef]

22. Ball, S.J. New class inequalities in education. Int. J. Sociol. Soc. Policy 2010, 30, 155-166. [CrossRef]

23. Hochschild, J.L. Social Class in Public Schools. J. Soc. Issues 2003, 59, 821-840. [CrossRef] 
24. Muller, C. Standards and Equity. J. Learn. Sci. 2004, 13, 237-242. [CrossRef]

25. Brayboy, B.M.J.; Castagno, A.E.; Maughan, E. Chapter 6 Equality and Justice For All? Examining Race in Education Scholarship. Rev. Res. Educ. 2007, 31, 159-194. [CrossRef]

26. Harper, S.R. Race without racism: How higher education researchers minimize racist institutional norms. Rev. High. Educ. 2012, 36, 9-29. [CrossRef]

27. Vasquez Heilig, J.; Brown, K.; Brown, A. The illusion of inclusion: A critical race theory textual analysis of race and standards. Harv. Educ. Rev. 2012, 82, 403-424. [CrossRef]

28. Klasen, S. Low Schooling for Girls, Slower Growth for All? Cross-Country Evidence on the Effect of Gender Inequality in Education on Economic Development. World Bank Econ. Rev. 2002, 16, 345-373. [CrossRef]

29. Meinck, S.; Brese, F. Trends in gender gaps: Using 20 years of evidence from TIMSS. Large-Scale Assess. Educ. 2019, 7, 8. [CrossRef]

30. UNESCO. Education for All Global Monitoring Report 2015: Gender Summary. 2015. Available online: https://en.unesco.org/ gem-report/report/2015/education-all-2000-2015-achievements-and-challenges (accessed on 2 November 2021).

31. Airton, L.; Koecher, A. How to hit a moving target: 35 years of gender and sexual diversity in teacher education. Teach. Teach. Educ. 2019, 80, 190-204. [CrossRef]

32. Badgett, M.V.L.Y.; Frank, J. (Eds.) Sexual Orientation Discrimination: An International Perspective; Routledge: New York, NY, USA, 2007.

33. Kosciw, J.; Greytak, E.; Diaz, E.; Bartkiewicz, M. The 2009 National School Climate Survey: The Experiences of Lesbian, Gay, Bisexual and Transgender Youth in Our Nation's Schools; Gay, Lesbian Straight Education Network: New York, NY, USA, 2010.

34. García, E.; Weiss, E. Reducing and Averting Achievement Gaps; Economic Policy Institute: Washington, DC, USA, 2017.

35. Shores, K.; Kim, H.E.; Still, M. Categorical Inequality in Black and White: Linking Disproportionality Across Multiple Educational Outcomes. Am. Educ. Res. J. 2020, 57, 2089-2131. [CrossRef]

36. Verstegen, D.A. On Doing an Analysis of Equity and Closing the Opportunity Gap. Educ. Policy Anal. Arch. 2015, $23,41$. [CrossRef]

37. Roche, R.; Manzi, J. Bridging the confidence gap: Raising self-efficacy amongst urban high school girls through STEM education. Am. J. Biomed. Sci. Res. 2019, 5, 452-454. [CrossRef]

38. Strietholt, R. Studying educational inequality: Reintroducing Normative Notions. In Educational Policy Evaluation through International Comparative Assessments; Strietholt, R., Bos, W., Gustafsson, J.-E., Rosén, M., Eds.; Waxmann: Münster, Germany, 2014; pp. 51-58.

39. Ainscow, M. Promoting inclusion and equity in education: Lessons from international experiences. Nord. J. Stud. Educ. Policy 2020, 6, 7-16. [CrossRef]

40. Noguera, P.; Pierce, J.; Ahram, R. Race, Equity, and Education: Sixty Years from Brown; Springer: New York, NY, USA, 2015.

41. OECD. Adapting Curriculum to Bridge Equity Gaps; OECD Publishing: Paris, France, 2021. [CrossRef]

42. Stephens, N.M.; Markus, H.R.; Fryberg, S.A. Social class disparities in health and education: Reducing inequality by applying a sociocultural self model of behavior. Psychol. Rev. 2012, 119, 723-744. [CrossRef] [PubMed]

43. Bannister, N.A. Breaking the spell of differentiated instruction through equity pedagogy and teacher community. Cult. Stud. Sci. Educ. 2016, 11, 335-347. [CrossRef]

44. McGee Banks, C.A.; Banks, J.A. Equity pedagogy: An essential component of multicultural education. Theory Pract. 1995, 34, 152-158. [CrossRef]

45. Lindsay, P.; Pitt, T.; Thomas, O. Bewitched by our words: Wittgenstein, language-games, and the pictures that hold sport psychology captive. Sport Exerc. Psychol. Rev. 2014, 10, 41-54.

46. Hjørland, B. Concept theory. J. Am. Soc. Inf. Sci. Technol. 2009, 60, 1519-1536. [CrossRef]

47. Suppe, F. Classification. In International Encyclopedia of Communications; Barnouw, E., Ed.; Oxford University Press: Oxford, UK, 1989; Volume 1, pp. 292-296.

48. Sinnott-Armstrong, W.; Wheatley, T. The Disunity of Morality and Why it Matters to Philosophy. Monist 2014, 95, 355-377. [CrossRef]

49. Carnap, R. Logical Foundations of Probability; University of Chicago Press: Chicago, IL, USA, 1950.

50. Maher, P. Explication Defended. Studia Log. 2007, 86, 331-341. [CrossRef]

51. Pawlowski, T. (Ed.) Concept Formation in the Humanities and the Social Sciences; Springer: Dordrecht, The Netherlands, 1980.

52. Espinoza, O. Solving the equity-equality conceptual dilemma: A new model for analysis of the educational process. Educ. Res. 2007, 49, 343-363. [CrossRef]

53. Hoang, A.-D. Fantastic educational gaps and where to find them: LERB-a model to classify inequity and inequality. J. Int. Educ. Pract. 2019, 2, 19-28. [CrossRef]

54. Tyler, W. The Sociology of Educational Inequality; Methuen: London, UK, 1977.

55. Moravcsik, A. Transparency in Qualitative Research. In SAGE Research Methods Foundations; Atkinson, P., Delamont, S., Cernat, A., Sakshaug, J.W., Williams, R.A., Eds.; SAGE Publications: London, UK, 2019. [CrossRef]

56. Makel, M.C.; Plucker, J.A. Toward a More Perfect Psychology: Improving Trust, Accuracy, and Transparency in Research; American Psychological Association: Washington, DC, USA, 2017. [CrossRef]

57. Miguel, E.; Camerer, C.; Casey, K.; Cohen, J.; Esterling, K.M.; Gerber, A.; Glennerster, R.; Green, D.P.; Humphreys, M.; Imbens, G.; et al. Promoting Transparency in Social Science Research. Science 2014, 343, 30-31. [CrossRef] [PubMed] 
58. Cambridge Dictionary. Transparency; Cambridge University Press: Cambridge, UK, 2021.

59. Hosseini, M.; Shahri, A.; Phalp, K.; Ali, R. Four reference models for transparency requirements in information systems. Requir. Eng. 2018, 23, 251-275. [CrossRef]

60. Jordan, W.J. Defining Equity: Multiple Perspectives to Analyzing the Performance of Diverse Learners. Rev. Res. Educ. 2010, 34, 142-178. [CrossRef]

61. Hämäläinen, N. Descriptive Ethics: What Does Moral Philosophy Know about Morality; Palgrave Macmillan: Basingstoke, UK, 2016.

62. Crisp, R. (Ed.) Oxford Handbook of the History of Ethics; Oxford University Press: Oxford, UK, 2013.

63. Bottiani, J.H.; Bradshaw, C.P.; Mendelson, T. A multilevel examination of racial disparities in high school discipline: Black and white adolescents' perceived equity, school belonging, and adjustment problems. J. Educ. Psychol. 2017, 109, 532-545. [CrossRef]

64. Penner, E.K.; Rochmes, J.; Liu, J.; Solanki, S.M.; Loeb, S. Differing Views of Equity: How Prospective Educators Perceive Their Role in Closing Achievement Gaps. RSF: Russell Sage Found. J. Soc. Sci. 2019, 5, 103-127. [CrossRef]

65. Becker, L.C. Places for pluralism. Ethics 1992, 102, 707-719. [CrossRef]

66. Timmons, M. Moral Theory: An Introduction; Rowman \& Littlefield Publishers: Lanham, MD, USA, 2012.

67. Bell, D. On meritocracy and equality. Public Interest 1972, 29, $29-68$.

68. Wolf, U. How Schopenhauer's ethics of compassion can contribute to today's ethical debate. Enrahonar Quad. Filos. 2015, 55, 41-49. [CrossRef]

69. UNESCO Institute for Statistics. Handbook on Measuring Equity in Education; UNESCO Institute for Statistics: Montreal, QC, Canada, 2018; p. 23. Available online: http://uis.unesco.org/sites/default/files/documents/handbook-measuring-equityeducation-2018-en.pdf (accessed on 2 November 2021).

70. Culyer, A.J. Equity—some theory and its policy implications. J. Med. Ethics 2001, 27, 275-283. [CrossRef] [PubMed]

71. Kashwan, P.; MacLean, L.M.; García-López, G.A. Rethinking power and institutions in the shadows of neoliberalism: (An introduction to a special issue of World Development). World Dev. 2019, 120, 133-146. [CrossRef]

72. Ceci, S.J.; Papierno, P.B. The Rhetoric and Reality of Gap Closing: When the "Have-Nots" Gain but the "Haves" Gain Even More. Am. Psychol. 2005, 60, 149-160. [CrossRef]

73. Omercajic, K.; Martino, W. Supporting transgender inclusion and gender diversity in schools: A critical policy analysis. Front. Sociol. 2020, 5, 27. [CrossRef] [PubMed]

74. Taylor, C.; Peter, T. Every Class in Every School: Final Report on the First National Climate Survey on Homophobia, Biphobia, and Transphobia in Canadian Schools; Egale Canada Human Rights Trust: Toronto, ON, Canada, 2011.

75. Carpenter, D.M.; Ramirez, A.; Severn, L. Gap or Gaps:Challenging the Singular Definition of the Achievement Gap. Educ. Urban Soc. 2006, 39, 113-127. [CrossRef]

76. Lee, C.D. Why We Need to Re-Think Race and Ethnicity in Educational Research. Educ. Res. 2003, 32, 3-5. [CrossRef]

77. Peters, S.J. The Challenges of Achieving Equity Within Public School Gifted and Talented Programs. Gift. Child Q. 2021, 00169862211002535. [CrossRef]

78. Tefera, A.A.; Powers, J.M.; Fischman, G.E. Intersectionality in Education: A Conceptual Aspiration and Research Imperative. Rev. Res. Educ. 2018, 42, vii. [CrossRef]

79. Borrell, L.N. Editorial: Critical race theory: Why should we care about applying it in our research? Ethn. Dis. 2018, 28, 215-218. [CrossRef] [PubMed]

80. McLoughlin, G.M.; McCarthy, J.A.; McGuirt, J.T.; Singleton, C.R.; Dunn, C.G.; Gadhoke, P. Addressing Food Insecurity through a Health Equity Lens: A Case Study of Large Urban School Districts during the COVID-19 Pandemic. J. Urban Health 2020, 97, 759-775. [CrossRef] [PubMed]

81. Ashiabi, G.S.; O'Neal, K.K. A Framework for Understanding the Association Between Food Insecurity and Children's Developmental Outcomes. Child Dev. Perspect. 2008, 2, 71-77. [CrossRef]

82. Faught, E.L.; Williams, P.L.; Willows, N.D.; Asbridge, M.; Veugelers, P.J. The association between food insecurity and academic achievement in Canadian school-aged children. Public Health Nutr. 2017, 20, 2778-2785. [CrossRef] [PubMed]

83. Winicki, J.; Jemison, K. Food Insecurity and Hunger in the Kindergarten Classroom: Its Effect on Learning and Growth. Contemp. Econ. Policy 2003, 21, 145-157. [CrossRef]

84. Stevenson, J.; Baker, S. Refugees in Higher Education: Debate, Discourse and Practice; Emerald Group Publishing: Sheffield, UK, 2018.

85. Ro, H.K.; Fernandez, F.; Ramon, E.J. Gender Equity in STEM in Higher Education: International Perspectives on Policy, Institutional Culture, and Individual Choice; Routledge: London, UK, 2021.

86. Waldfogel, H.B.; Sheehy-Skeffington, J.; Hauser, O.P.; Ho, A.K.; Kteily, N.S. Ideology selectively shapes attention to inequality. Proc. Natl. Acad. Sci. USA 2021, 118, e2023985118. [CrossRef]

87. Kohlberg, L.; Mayer, R. Development as the Aim of Education. Harv. Educ. Rev. 2012, 42, 449-496. [CrossRef]

88. OECD. International Standard Classification of Education. ISCED 2011; UNESCO Institute for Statistics: Montreal, QC, Canada, 2012.

89. McClelland, K.; Fararo, T. Purpose, Meaning, and Action: Control Systems Theories in Sociology; Palgrave Macmillan: New York, NY, USA, 2006.

90. Nowak, A.; Vallacher, R.R. Dynamical Social Psychology; Guilford Press: New York, NY, USA, 1998.

91. Robinson, D.T. Control Theories in Sociology. Annu. Rev. Sociol. 2007, 33, 157-174. [CrossRef]

92. Kohli, R.; Pizarro, M.; Nevárez, A. The "New Racism" of K-12 Schools: Centering Critical Research on Racism. Rev. Res. Educ. 2017, 41, 182-202. [CrossRef] 
93. Education Reform. Achievement Gap. Available online: https://www.edglossary.org/achievement-gap/ (accessed on 14 August 2021).

94. Education Reform. Opportunity Gap. Available online: https://www.edglossary.org/opportunity-gap/ (accessed on 14 August 2021).

95. Education Reform. Learning Gap. Available online: https:/ /www.edglossary.org/learning-gap/ (accessed on 14 August 2021).

96. Coleman, J.S.; Campbell, E.Q.; Hobson, C.J.; McPartland, J.; Mood, A.M.; Weinfeld, F.D.; York, R.L. Equality of Educational Opportunity (Report OE-38000); US Department of Health Education and Welfare, Office of Education: Washington, DC, USA, 1966.

97. Francis, P.; Broughan, C.; Foster, C.; Wilson, C. Thinking critically about learning analytics, student outcomes, and equity of attainment. Assess. Eval. High. Educ. 2020, 45, 811-821. [CrossRef] 